\title{
PARTISIPASI SOSIAL PEREMPUAN DALAM PEMBANGUNAN DESA LASIAI KECAMATAN SINJAI TIMUR KABUPATEN SINJAI
}

\author{
Jumiati Abdullah ${ }^{1}$, Nursalam ${ }^{2}$, Sudarsono ${ }^{3}$ \\ ${ }^{1}$ Pendidikan Sosiologi, Universitas Muhammadiyah Makassar \\ Email: abdullahjumiati1@gmail.ac.id \\ 2Pendidikan Sosiologi, Universitas Muhammadiyah Makassar \\ Email: nursalam@unismuh.ac.id \\ ${ }^{3}$ Pendidikan Sosiologi, Universitas Muhammadiyah Makassar \\ Email: sudarsono@unismuh.ac.id
}

\begin{abstract}
This study examines the social participation of women in the development of the village of Lasiai, East Sinjai Subdistrict, Sinjai District. The problem in this research is how the form of social participation of women in the development of the village of Lasiai and how the impact of social participation of women in the development of the village of Lasiai, East Sinjai Subdistrict, Sinjai District. The purpose of this study was to determine the forms of women's social participation in the development of Lasiai villages and to determine the impact of women's social participation in the development of Lasiai Village in the East Sinjai Subdistrict, Sinjai District. This type of research is a descriptive study with a qualitative approach. The informants in this study were the village head, village secretary, village head, PKK mother. Data collection was collected using observation techniques, interviews, and documentation. Data analysis techniques are data reduction, data presentation, and drawing conclusions. Triangulation is used to explain the validity of the data that is with the data source.

The results showed that the form of women's social participation in the development of the village of Lasiai was through the first three stages, namely the planning stage, that women were present in the deliberation meeting held with village officials, Second, the implementation stage by increasing empowerment as a program such as the Al-qur 'love program. and active standby village programs. Third, the participation monitoring phase aims to find out how the implementation of development programs will work, and the impact of women's social participation in village development is a) positive impacts, namely open thinking (education), the economy, and women's leadership b) negative impacts, namely labeling or the stereotype of society towards women.
\end{abstract}

Keywords: Participation, women, village development

Abstrak. Penelitian ini mengkaji tentang partisipasi sosial perempuan dalam pembangunan desa lasiai kecamatan sinjai timur kabupaten sinjai. Masalah dalam penelitian ini adalah bagaimana bentuk partisipasi sosial perempuan dalam pembangunan desa lasiai dan bagaimana dampak partisipasi sosial perempuan dalam pembangunan desa lasiai kecamatan sinjai timur kabupaten sinjai. Tujuan penelitian ini adalah untuk mengetahui bentuk partisipasi sosial perempuan dalam pembangunan desa lasiai dan untuk mengetahui dampak partisipasi sosial perempuan dalam pembangunan desa lasiai kecamatan sinjai timur kabupaten sinjai. Jenis penelitian ini adalah penelitian deskriptif dengan pendekatan kualitatif. Informan dalam penelitian ini adalah Kepala Desa, Sekertaris Desa, Kepala Dusun, Ibu PKK. Pengumpulan data dikumpulkan dengan teknik pengamatan (Observasi ), wawancara, dan dokumentasi. Teknik analisis data adalah reduksi data, penyajian data, dan penarikan kesimpulan. Trianggulasi yang digunakan untuk menjelaskan keabsahan data yaitu dengan sumber data.

Hasil penelitian menunjukkan bahwa bentuk partisipasi sosial perempuan dalam pembangunan desa lasiai yaitu melalui tiga tahap yang pertama yaitu tahap perencanaan adalah perempuan hadir dalam kegiatan rapat musyawarah yang dilakukan bersama aparat desa, Kedua yaitu tahap pelaksanaan dengan meningkatkan 
pemberdayaan sebagai program seperti program cinta Al-qur'an dan program desa siaga aktif. Ketiga yaitu tahap pengawasan partisipasi ini bertujuan untuk mengetahui bagaimana pelaksanaan program pembangunan akan berjalan, dan Dampak partisipasi sosial perempuan dalam pembangunan desa adalah a) dampak positif yaitu pemikiran mulai terbuka (Pendidikan), perekonomian, dan kepemimpinan perempuan b) dampak negatif yaitu adanya pemberian label atau streotipe masyarakat terhadap perempuan.

Kata kunci : Partisipasi, Perempuan, Pembangunan Desa

\section{PENDAHULUAN}

Pembangunan suatu desa membutuhkan partisipasi masyarakat yang merupakan modal utama dalam mencapai suatu program pembangunan karena keberhasilan program pembangunan sangat berhubungan dengan upaya masyarakat untuk mewujudkan kemampuan dan potensi untuk pelaksanaan program kedepannya. Oleh karena itu dibutuhkan kerja sama antara pemerintah desa dengan masyarakat termasuk peran perempuan dalam pelaksanaan pembangunan. Keikutsertaan perempuan dalam pembangunan banyak menimbulkan persepsi dan anggapan yang berbedaberbeda dari masyarakat dalam menempatkan posisi perempuan dalam lingkungan sosial yang banyak dipengaruhi oleh pola pikir masyarakat yang masih tradisional dengan memposisikan perempuan berbeda dengan laki-laki. Hal yang paling diharapkan oleh kaum perempuan adalah adanya persamaan hak baik dalam politik, ekonomi, dan berbagai bidang lainnya. Untuk mencegah terjadinya diskriminasi atau perbedaan penempatan posisi dalam hal pekerjaan serta pada kemampuan mereka dalam mendapatkan penghargaan dan apresiasi terhadap pencapaian perempuan.

Peran perempuan dalam pelaksanaan pembangunan sudah banyak dilakukan oleh kaum perempuan, bahkan dalam penyelenggaraan pembangunan. Sudah banyak perempuan yang ikut berpartisipasi dalam pemerintahan desa, dan tidak sedikit dari mereka banyak mencapai prestasi. Hal ini banyak dipengaruhi oleh kemampuan dalam hal pendidikan, pengalaman, dan kemauan perempuan itu sendiri. Kesadaran perempuan untuk ikut memberikan kontribusi dan partisipasi dalam pembangunan sangat mendukung adanya program yang dicanangkan pemerintah desa yang mengharapkan kesadaran masyarakatnya untuk bisa memberikan ide dan gagasan mereka mengenai program-program yang akan dilaksanakan. Termasuk pembangunan yang direncanakan di Desa Lasiai. Desa ini berada di kecamatan sinjai timur kabupaten Sinjai, Sulawesi Selatan. Desa ini terletak $16 \mathrm{~km}$ dari ibu kota kabupaten yang berada ada ketinggian $300 \mathrm{~m}$ spl. Kepala pemerintah Desa lasiai yang di kepalai oleh Ambo Tuo melaksanakan musyawarah desa (Mudes) rencana pembangunan ( RKP) tahun 2018. Mudes ini merupakan langkah awal pemerintah desa untuk menampung segala bentuk program yang diusulkan oleh masyarakat kemudian memilih dan menetapkan menjadi skala prioritas dengan mempertimbangkan asas manfaat terhadap masyarakat.

Pemerintah Desa Lasiai mengharapkan semua masyarakat dapat memberikan konstribusi untuk mencapai kemajuan Desa, termasuk perempuan di Desa Lasiai sudah sangat terbuka dalam hal memberikan sumbangsih dalam perencanaan program pembangunan, Yang salah satu program yang dicanangkan pemerintah Desa yang sangat memerlukan kontribusi dan partisipasi kaum perempuan adalah program pemberdayaan kesejahteraan keluarga ( PKK ).

Pemerintah Desa bekerja sama dengan masyarakat untuk membangun Pondasi Al-Qur'an. Pemerintah Desa Lasiai senantiasa membuka ruang kepada seluruh masyarakat diantaranya para anggota PKK agar bisa aktif memberikan konstribusi dalam pembangunan di semua aspek. Oleh karena itu kepala Desa meminta kepada masyarakat agar mendukung program yang akan direncanakan kedepannya yaitu desa lasiai akan dijadikan sebagai kampung literasi dan gemar membaca Al-qu'an. Dengan program ini diharapkan partisipasi dan kerja sama dari ibu-ibu di desa lasiai yang nantinya bisa mengajarkan anak-anak untuk membaca dan mempelajari Al-qur'an. 


\section{METODE PENELITIAN}

Penelitian ini adalah jenis penelitian kualitatif, meliputi rangkaian kegiatan yang sistematik untuk mendapatkan jawaban dari permasalahan yang diajukan. Jika dilihat dari jenis dan objek yang diteliti, penelitian ini mengkaji tentang partisipasi sosial perempuan dalam pembangunan desa lasiai kecamatan sinjai timur kabupaten sinjai. Penelitian ini akan di laksanakan selama kurang lebih dua bulan yakni bulan April sampai dengan bulan Mei 2018 di Desa Lasiai Kecamatan Sinjai Timur Kabupaten Sinjai.

Hal-hal yang menjadi sasaran dalam penelitian ini adalah peranan para kader dan anggota PKK dalam masyarakat desa Lasiai Kecamatan Sinjai Timur Kabupaten Sinjai. Untuk mengetahui informasi dari beberapa resonden sebagai sampel dengan teknik purosive sampling (peneliti memilih sampel sendiri yang dianggap mampu memberikan informasi mengenai apa yang akan diteliti). Informan di pilih sebanyak 6 orang yang terdiri atas Kepala desa Lasiai, Sekertaris desa, Tokoh Masyarakat, Kepala Dusun, dan 3 orang anggota PKK yang diangga mampu memberikan informasi mengenai partisipasi sosial perempuan dalam pembangunan desa Lasia Kecamatan Sinjai Timur Kabupaten Sinjai. Semakin banyak data yang di peroleh maka semakin bagus untuk hasil penelitian. Dalam penelitian mengenai Partisipasi Sosial Perempuan dalam Pembangunan Desa Lasiai Kecamatan Sinjai Timur Kabupaten Sinjai yakni studi pustaka, observasi langsung, wawancara, dan dokumentasi. Teknik analisis data yang digunakan peneliti adalah teknik analisis data kualitatif melalui analisis yaitu reduksi kata kemudian penyajian data yang tersusun dalam laporan tulisan yang dijelaskan bersifat naratif kemudian menarik kesimpulan akhir dalam penelitian.

\section{HASIL DAN PEMBAHASAN}

Setelah melakukan observasi, wawancara, dan dokumentasi di lapangan maka akan disajikan data-data yang diperoleh dari penelitian. Untuk lebih jelasnya dapat dilihat sebagai berikut :

\section{Bentuk Partisipasi Sosial Perempuan dalam Pembangunan Desa Lasiai Kecamatan Sinjai Timur Kabupaten Sinjai}

\section{Partisipasi Perempuan dalam Perencanaan Pembangunan}

Bentuk partisipasi perempuan dalam perencanaan pembangunan di Desa Lasiai yaitu perempuan hadir dalam kegiatan rapat dan musyawarah yang dilakukan bersama aparat Desa dengan memberikan masukan dan informasi saat musyawarah tersebut. Oleh karena itu elemen masyarakat yang berhubungan dengan perencanaan pembangunan Desa. Selain itu uga berpartisipasi untuk memberikan tahukan kepada masyarakat sekitar untuk menumbuhkan sikap gotong royong dan menjadikan Desa Lasiai menjadi desa yang mampu bekerja sama dengan baik. Seperti yang diungkapkan oleh Bapak yang berinisial " $\mathrm{CL}$ " selaku tokoh masyarakat bahwa ;

"Desa Lasiai adalah Desa yang selalu mengutamakan gotong royong dan bahkan hanya kegiatan kecil-kecil saja, masyarakat akan ikut membantu. Hal ini sudah menjadi kebiasaan masyarakat Lasiai. Setiap ingin melaksanakan program di Desa, Kepala Desa akan memberitahuan kepada masyarakatnya untuk rapat sebelum memutuskan apa yang menjadi keputusan bersama, sehingga masyarakat bisa memberikan masukan-masukan apa yang terbaik untuk Desa". ( Wawancara pada hari Jumat 06 April 2018 ) berikut ;

Selain itu diungkapkan oleh bapak yang berinisial "AT " selaku kepala Desa Lasiai sebagai

"Masyarakat memiliki kesempatan yang sama untuk memberikan konstribusi dan pendapat apabila ada suatu kegiatan atau program yang direncanakan, oleh karena itu 
dibutuhkan kerja sama yang baik dari masyarakat sehingga setiap masyarakat merasa bebas untuk berpendapat dan mengeluarkan ide-ide yang mampu membangun Desa Lasiai menjadi desa yang unggul dan berprestasi ". (Wawancara pada hari Jumat 06 April 2018)

Keterangan tersebut diperkuat oleh bapak yang berinisial " HB " selaku Sekertaris Desa Lasiai yaitu sebagai berikut ;

"Setiap rapat yang diadakan masyarakat ikut memberikan sumbangsi dan masukan ide atau pendapat mereka yang meminta untuk melakukan perbaikan, dalam rapat ini tidak ketinggalan partisipasi perempuan, dan banyak dari kaum perempuan yang mengambil bagian dalam setiap perencanaan program yang akan dilaksanakan". (Wawancara pada hari Jumat 06 April 2018)

\section{Partisipasi Perempuan dalam Pelaksanaan Program Pembangunan}

\section{a. Program Cinta Al-Qur'an}

Program ini dilaksanakan dengan baik oleh sekelompok perempuan di Desa Lasiai, Salah satu penggerak dalam pelaksanaan program desa siaga aktif ini adalah dari ibu PKK dan para kadernya. Cinta Al-qur'an adalah seorang ibu rumah tangga yang berinisial " LI " selaku guru TK-TPA Miftahul jannah menuturkan bahwa :

"Salah satu program yang canangkan pemerintah Desa sangat bagus untuk anak-anak khususnya di Desa lasiai karena banyak sekali anak-anak yang memang sangat membutuhkan tempat untuk belajar membaca Al-qur'an sehingga anak-anak di sini mampu ikut berpartisipasi dalam setiap lomba yang biasa di adakan oleh Desa yang bertujuan untuk membuat anak-anak semakin termotivasi untuk terus belajar Al-qur'an ". (Wawancara pada hari Selasa 10 April 2018)

Sama halnya bapak yang berinisial "AT " selaku Kepala Desa Lasiai, sebagai berikut :

"Banyaknya anak-anak di Desa Lasiai yang memiliki potensi untuk menjadi seorang penghafal Al-qur'an. Oleh karena itu di butuhkan seorang guru atau pengajar yang bisa membantu anak-anak untuk terus belajar Al-qur'an, karena saya ingin menjadikan Desa Lasiai menjadi kampung pencinta Al-qur'an. Biasanya sering di laksanakan lomba untuk meningkatkan kemampuan anak-anak dan sekaligus mengevaluasi sampai di mana anakanak memahami apa yang sudah di ajarkan kepada mereka. Oleh karena itu suatu kesyukuran bagi saya karena memiliki warga yang bisa bekerja sama dengan baik, khususnya perempuan terlihat dari setiap program yang dilaksanakan banyak dari ibu-ibu ikut berpartisipasi seperti dalam hal kesehatan perempuan juga banyak memberi konstribusi terhadap masyarakat Desa Lasiai, dengan kerja sama antara ibu-ibu PKK dengan bidan Desa saling membantu mengontrol masyarakat untuk pemeriksaan kesehatan setiap bulannya". (Wawancara pada hari Selasa 10 April 2018 )

Diperkuat oleh pernyataan ibu yang berinisial " LI " selaku guru mengaji TK-TPA sebagai berikut:

"Program ini sudah berjalan selama 10 tahun sejak berdirinya TK-TPA Miftahul Jannah berdiri pada tahun 2009 pada saat pemerintah Desa sebelumnya yaitu pak Muhammad Anas, kemudian di lanjutkan oleh kepala desa yang sekarang, bapak Ambo Tuo dengan 
program kampung cinta Al-qu'an. Dengan adanya TK-TPA ini anak-anak di Dusun Korasa Desa Lasiai bisa banyak mempelajari Al-qur'an dengan baik, dengan lomba yang biasa di lakasanakan yaitu Penghafalan Surah Pendek, Bacaan Sholat, Menghafal Ayat-Ayat Pilihan, Doa Harian. Hal ini mampu mengasah kemampuan anak-anak untuk menghafal Al-qur'an.(Wawancara pada hari Rabu 11 April 2018)

\section{b. Program Desa Siaga Aktif}

Program perencanaan yang akan di lakasanakan pada program pelaksanaannya sesuai dengan tanggapan bapak kepala desa lasiai yang berinisial "AT " selaku Pembina dalam terbenruknya forum desa siaga sebagai berikut :

"Dengan terbentuknya forum desa siaga ini diharapkan semua pengurus forum desa siaga dan para kadernya mampu memberikan partisipasi terhadap setiap program yang sudah di rencanakan agar bukan hanya sekedar program saja tetapi mampu memberikan bukti nyata terhadap masyarakat khususnya masyarakat desa lasiai. Program yang memberikan konstribusi besar mengenai kepedulian masyarakat terhadap kesehatan ". (Wawancara pada hari Kamis 12 April 2018)

Begitu juga pernyataan di tambahkan oleh ibu yang berinisial " $\mathrm{SI}$ " selaku anggota PKK dan sekaligus sebagai ketua forum desa siaga aktif sebagai berikut :

"Forum desa siaga aktif ini sebagai wadah untuk ibu PKK dan juga para kader untuk memberikan partisipasi mereka terhadap salah satu pelaksanaan program pembangunan yang di canangkan pemerintah desa lasiai yang bekerja sama langsung dengan ibu-ibu PKK kabupaten sinjai dan juga perwakilan dari setiap petugas kesehatan, agar mampu melakukan sosialisasi kepada masyarakat tentang pentingnya menjaga kesehatan ".

(Wawancara pada hari Kamis 12 april 2018)

\section{c. Partisipasi Perempuan dalam Pengawasan Program Pembangunan Desa Lasiai}

Perempuan sudah mengambil peran dalam pemerintahan seperti halnya perempuan di beri kepercayaan untuk memimpin masyarakatnya, hal ini di dukung dengan kemampuan dan kemauan perempuan dalam memberikan partisipasi terhadap

pembangunan desa. Seperti yang diutarakan oleh bapak yang berinisial " AT " selaku

Kepala Desa Lasiai sebagai berikut :

"Salah satu keberhasilan suatu program yang akan di laksanakan adalah apabila setiap masyarakat mampu menjaga kerja sama mereka, dengan terus menjalin komunikasi. Saya selaku kepala Desa Lasiai sangat bersyukur atas kerja sama yang baik dari para masyarakat termasuk perempuan yang selalu memperlihatkan partisipasi mereka dalam melaksanakan setiap program pembangunan dan juga partisipasi dari setiap kepala dusun desa lasiai yang terus membangun kerja sama agar setiap program yang akan di laksanakan bisa di capai dengan baik ". (Wawancara pada hari Senin 16 April 2018 )

Begitu pun pernyataan dari ibu yang berinisial " IW " selaku kepala dusun desa lasiai adalah sebagai berikut :

"Yang memotivasi saya untuk ikut berpartisipasi dalam setiap program yang di rencanakan dalam pembangunan di Desa Lasiai, salah satunya adalah kemampuan kepala Desa Lasiai untuk merangkul semua masyarakat untuk terus bekerja sama dalam 
menjalankan setiap program pembangunan. Hal ini juga membuat saya untuk terus memberikan partisipasi yang membangun untuk Desa Lasiai seperti ikut membantu ibu PKK dalam menjalankan setiap program yang di rencanakan ".( Wawancara pada hari Senin 16 April 2018)

Diperkuat oleh pernyataan bapak yang berinisial " AT " selaku kepala desa lasiai adalah sebagai berikut :

"Sudah banyak kegiatan desa yang melibatkan partisipasi perempuan termasuk mudes, selalu memberi kesempatan perempuan untuk memberikan ide dan pemikiran mereka mengenai program apa yang baik untuk pembangunan desa kedepannnya. Dan baru-baru ini dalam pemilihan calon Bupati dan wakil Bupati Sinjai, tim pengawas TPS banyak di rekrut dari kaum perempuan. Hal ini jelas sekali bahwa kami tidak membatasi perempuan dalam setiap perencanaan desa. Tergantung dari mereka ingin berpartisipasi atau tidak, akan tetapi sangat bagus kalau mereka memiliki kesadaran sendiri untuk memberikan partisipasi mereka ". (Wawancara pada hari Senin 16 April 2018).

\section{Dampak Partisipasi Sosial Perempuan dalam Pembangunan Desa Lasiai Kecamatan Sinjai Timur Kabupaten Sinjai}

\section{a. Dampak Positif Partisipasi Sosial Perempuan dalam Pembangunan Desa}

\section{Pemikiran Perempuan Terbuka}

Sudah banyak perempuan membuktikan dengan adanya pendidikan dan pengetahuan yang baik, maka perempuan diberikan kesempatan yang sama untuk ikut berpartisipasi dalam setiap pembangunan yang akan di laksanakan. Ditambahkan oleh bapak yang berinsial " AT " selaku kepala desa lasiai sebagai berikut :

"Pendidikan adalah salah satu hal yang sangat penting dalam kehidupan manusia, karena dengan adanya kemampuan pengetahuan dan pengalaman pada diri seseorang maka akan diberi kesempatan kerja yang baik pula untuk mereka. Seperti halnya perempuan. Dengan kemauan dan pengetahuan yang mereka miliki, akan membuat mereka bisa ikut berpartisipasi dalam perencanaan sampai pada tahap pengawasan program pembangunan desa ".

(Wawancara pada hari Selasa 17 April 2018)

Diperkuat dengan pernyataan ibu yang berinisial "IW " selaku ibu kepala dusun korasa desa lasiai sebagai berikut :

"Saya sebagai kepala dusun perempuan di desa lasiai, sangat bersyukur karena bisa di libatkan dalam setiap perencanaan program desa. Dengan kesadaran penuh bahwa kemauan dan tekad saja tidak cukup untuk ikut memberi konstribusi atau partisipasi kita akan tetapi di butuhkan pengetahuan dan pendidikan yang cukup untuk ikut berpartisipasi. Dan sekarang dalam pemilihan kepala dusun tidak hanya di lihat dari kemampuan menaungi masyarakat tetapi di lihat juga tingkat pendidikan yang sudah di tempuh". (Wawancara pada hari Selasa 17 April 2018 ) 


\section{Perekonomian} berikut :

Sesuai dengan pernyataan ibu yang berinisial " LI " selaku guru TK-TPA adalah sebagai

"Dengan adanya kesibukan selain dari pekerjaan rumah, setiap 3 kali dalam satu minggu setiap sorenya. Memberikan kesibukan tersendiri buat saya. Hal ini saya anggap sebagai cara saya berpartisipasi dalam setiap program pembangunan yang di canangkan pemerintah untuk menjadikan desa sebagai kampung literasi dan cinta Al-qu'an ". (Wawancara pada hari Selasa 17April 2018)

Diperkuat oleh pernyataan ibu yang berinisial " IW " selaku Ibu kepala dusun korasa desa lasiai sebagai berikut :

"Diberikannya kesempatan kerja yang sama, perempuan memiliki kesempatan untuk berpartisipasi langsung dalam pembangunan desa. Dan saya sebagai seorang aparat desa memiliki tanggung jawab untuk menjalankan tugas sebagaimana mestinya, hal ini juga sejalan dengan tugas yang di berikan. Secara langsung dengan ikutnya berpartisipasi dalam menjalankan pekerjaan ini memengaruhi perekonomian ". (Wawancara pada hari Selasa 17 April 2018)

\section{Kepemimpinan Perempuan}

Menurut penuturan ibu yang berinisial " SI " selaku anggota PKK sebagai berikut :

"Sekarang dengan kemajuan teknologi, pemikiran masyarakat juga mulai terbuka dengan hal-hal baru. Seperti halnya pemimpin perempuan yang tidak di lihat lagi dari posisi perempuannya tetapi bagaimana kemampuan mereka. Itu yang dilihat sekarang ".

(Wawancara pada hari Rabu 18 April 2018)

Ketika mewawancarai bapak yang berinisial " $\mathrm{CL}$ " selaku tokoh masyarakat desa lasiai hamper sama dengan informan yang berinisial " $\mathrm{SI}$ " ia juga menambahkan bahwa :

"Untuk menjadi seorang pemimpin tidak hanya lihat dia itu laki-laki atau perempuan tapi bagaimana mereka mampu menalankan tugas yang di berikan. Persoalan laki-laki dan perempuan sekarang sudah tidak menjadi permasalahan, tidak kaya dulu-dulu. Dulu itu laki-laki yang akan di jadikan pemimpin dan perempuan hanya mengikuti. Dan yang paling penting dulu perempuan kerjaannya di rumah mengurus anak-anak mereka dan tidak pernah berpikir untuk menjadi seorang pemimpin. Tidak seperti sekarang dengan pendidikan yang di miliki, perempuan juga memiliki kesempatan yang sama dengan lakilaki, selama mereka mampu menjalankan tugas mereka sebagai seorang pemimpin ".

(Wawancara pada hari Rabu 18 April 2018)

Begitu juga dengan penuturan bapak yang berinisial " $\mathrm{HI}$ " selaku sekretaris desa lasiai adalah sebagai berikut :

"Sekarang tidak menjadi permasalahan antara laki-laki dan perempuan, mereka mempunyai hak dan kewajiban yang sama untuk membuat desa menjadi maju. Baik itu desa di pimpin oleh seorang laki-laki maupun perempuan, yang paling penting adalah kerja dan bukti mereka untuk melaksanakan program-program pembangunan yang 
bertujuan untuk menjadikan desa lasiai menjadi desa yang unggul dan mampu mensejahterakan masyarakatnya ". (Wawancara pada hari Rabu 18 April 2018)

\section{b. Dampak Negatif Partisipasi Sosial Perempuan dalam Pembangunan Desa}

\section{1) Streotipe atau Pelabelan Masyarakat}

Menurut informan yang berinisial " LI " selaku guru TK-TPA mengatakan bahwa :

"Banyak dari masyarakat melihat bahwa apa yang kita lakukan dalam pembangunan desa, atau ikut berpartisipasi dalam setiap perencanaan pembangunan, katanya tindakan kita sudah sangat jauh untuk mengurus pekerjaan desa sedangkan banyak pekerjaan di rumah yang harus di urusi. Akan tetapi saya merasa sebagai pelopor pembangunan memiliki kewajiban untuk bekerja sama dengan desa, dan selama saya bisa membagi waktu dengan pekerjaan rumah dan mengajar anak-anak, saya rasa tidak menjadi masalah ". (Wawancara pada hari Rabu 18 April 2018)

Diperkuat dengan pernyataan ibu yang berinisial " IW " selaku kepala dusun desa lasiai mengatakan sebagai berikut :

"Saya selaku kepala dusun di desa lasiai menganggap bahwa masyarakat yang menganggap perempuan yang bekerja di ranah public dan menganggap bahwa hal itu telah melanggar kodratnya sebagai seorang perempuan. Hal itu terjadi karena kebanyakan masyarakat belum mengerti dan masih berpikir tradisional yang menganggap bahwa hanya kaum laki-laki yang bisa memimpin. Tetapi menurut saya selama kita mampu menjalankan kewajiban kita sebagai seorang pemimpin meskipun seorang perempuan itu tidak menjadi suatu masalah ". (Wawancara pada hari Rabu 18 April 2018)

Ditambahkan oleh ibu yang berinisial " SI " selaku anggota PKK desa lasiai mengatakan bahwa :

"Untuk masyarakat yang menganggap bahwa perempuan yang ikut berpartisipasi dalam program perencanaan pembangunan telah melanggar kodrat sebagai seorang perempuan, itu hanya masalah kurang memahami saja. Karena sebenarnya laki-laki dan perempuan memiliki hak dan kewajiban yang sama untuk meningkatkan dan memajukan desanya". (Wawancara pada hari Rabu 18 April 2018)

\section{KESIMPULAN}

Partisipasi sosial perempuan dalam pembangunan desa dalam hal ini di Desa Lasiai, peran perempuan sangat terlihat dengan keinginan perempuan untuk memberikan kontribusi dalam pelaksanaan program-program desa seperti ada dua program yang dilaksanakan yaitu program cinta Al-qu'an dan program desa siaga aktif. Dengan adanya program ini perempuan yang memiliki kesadaran penuh untuk meningkatkan pembangunan desa lasiai, mereka bekerja sama dengan aparat desa untuk membangun desa lebih baik ke depannya. Adapun bentuk partisipasi perempuan dalam pembangunan yaitu mulai dari tahap perencanaan, tahap pelaksanaan, sampai pada tahap pengawasan. 


\section{DAFTAR PUSTAKA}

Aziz Ali. 2005. Pendekatan Sosio-Kultur dalam Pemberdayaan Masyarakat.Yogyakarta: LKIS Fakih Mansoer. 2013. Analisis Gander dan Transformasi Sosial. Yogyakarta: Pustaka Pelajar

Kadarusman. 2005. Agama, Relasi dan Feminisne. Yoyakarta: Kreasi Wacana

Luhur Pumbudiyono. 2012. Partisipasi Politik Perempuan dalam Pembangunan Infrastruktur Pedesaan. Skripsi tidak dipublikasikan. Yogyakarta: Universitas Negeri Yogyakarta

Mansyur Yahya. 2007. Model Pengembangan Masyarakat Pedesaan. Yogyakarta : PT LKiS Printing Cemerlang

Mikelsen. 2005. Konsep Partisipasi. Dalam Isbandi Rukuminto ( Ed ). Intervensi Komunitas dan Pembangunan Masyarakat sebagai Upaya Pemberdayaan Masyarakat. Jakarta: PT. Raja Grafindo Persada

Moree Hallen. 2002. Sosiologi Wanita. Jakarta : PT Rineka Cipta

Nugroho Riant. 2008. Konteks Pemberdayaan Perempuan. Tim Perumus Strategi Pembangunan Nasional

Nurhikmah. 2012. Komunitas Perempuan Pengumpul Semen Buangan di Desa Biring Ere Kabupaten Pangkep. Skripsi tidak diterbitkan. Makassar : Universitas Muhammadiyah Makassar

Rukuminto Isbandi. 2012. Intervensi Komunitas dan Pengembangan Masyarakat sebagai Upaya Pemberdayaan Masyarakat. Jakarta : PT. Raja Grafindo Persada

Rukuminto Isbandi. 2015. Kesejahteraan Sosial ( Pekerjaan Sosial, Pembangunan Sosial, dan Kajian Pembangunan ). Jakarta : Rajawali Pers

Salma.2011. Pengarustamaan Gender dalam Pengambilan Kebijakan di Sekretariatan Daerah Kabupaten Pangkep. Skripsi tidak diterbitkan. Makassar: Universitas Muhammadiyah Makassar

Siti Irene Astuti Dwiningsih ( 2011 ) . Desentralisasi dan Partisipasi Masyarakat dalam Pendidikan. Yogyakarta : Pustaka Pelajar

Suhartini, dkk. 2005. Model-Model Pemberdayaan Masyarakat. Yogyakarta: Pustaka Pesantren

Sugiyono ( 2016 ). Metode Penelitian Kualitatif Kuantitatif dan R \& D. Bandung :

CV. Alfabeta

Supartinah. 2010. Partisipasi Perempuan dalam Struktur Desa ( Studi Kasus Desa Pekelan Kecamatan Madukara Kabupaten Banjarnegara ). Skripsi tidak dipublikasikan. Yogyakarta: Universitas Negeri Yogyakarta

Upe Ambo. 2010. Tradisi Aliran dalam Sosiologis dari Filosofi Positivistik ke Post Positivistik. Jakarta: Rajawali Pers

Irma Suriani. 2017. Eksistensi Perempuan dalam Budaya Partiriarki pada masyarakat Jawa di Desa WonoRejo Kecamatan Mangkutana Kabupaten Luwu Timur. Skripsi tidak diterbitkan. Makassar : Universitas Muhammadiyah Makassar.

\section{Sumber Online :}

Muzawah. 2010. Pemberdayaan Perempuan dalam Pembangunan Berbasis Pertisipasi. ( Online ), Vol. 2. No 2

Nugroho Riant. 2008. Pemberdayaan Perempuan. ( Online ), (www. Deskop. Go.id) di akses 29 Januari 2018

Nasir Rahmah Rahayu Sri. 2014. Perubahan Sosial Masyarakat Lokal Akibat Perkembangan Pariwisata Dusun Wakka Kabupaten Pinrang (Interaksi Masyarakat Lokal dan Wisatawan) . Skripsi tidak diterbitkan. Makassar : Universitas Hasanuddin Makassar 